\title{
Enriching Students' Vocabulary Mastery through English Spelling Bee Games
}

\author{
Putri Tria Pratiwi \\ IAIN Bengkulu \\ putri@gmail.com \\ Fera Zasrianita \\ IAIN Bengkulu \\ ferazasrianita@iainbengkulu.ac.id \\ Ali Akbarjono \\ IAIN Bengkulu \\ aliakbarj250975@gmail.com
}

\begin{abstract}
This research aims to enriching students vocabulary mastery by using spelling bee games. The population of this research was the seventh grade students of SMP Negeri 15 Kota Bengkulu with consisted of 180 students into seven classes, namely VII A - VII F. After ensuring with the purposive sampling, two classes were finally chosen as the sample of this research: VII D as the experimental class and VII E as the control class. Both of classes consisted of 30 students with almost homogenous score. This research had been conducted at SMP Negeri 15 Kota Bengkulu. This research employed a Quasi-Experimental method. The Experimental class treated by using Spelling Bee strategy, while the control class was using the conventional ways. The pre-test was given to the two groups before giving the treatment. The result of pre-test showed the mean score of experimental class was 60.17 and the control class was 59.83. After giving the treatment, post-test was given. The result of post-test showed the mean score of experimental class was 76.00 and the control class was 69.83. in addition, the result of independent sample T-test (0.094) showed that t-count was smaller than t-table (2.00172) and sig (2-tailed) was higher than $0.05(0.925>0.05)$. In other words, Ho was accepted and Ha was rejected. In summary, it could be stated that students' who were taught vocabulary by using Spelling Bee was more effective than using the conventional ways. So, it can be concluded that Spelling Bee has positive effect to the Seventh Grade Students' at SMP Negeri 15 Kota Bengkulu in vocabulary Mastery.
\end{abstract}

Keywords: Spelling Bee Games, Vocabulary Mastery

\section{A. Introduction}

This research attempts to enrich the students' vocabulary mastery by using spelling bee games at several classes (seventh grade) students of SMP Negeri 15 Kota Bengkulu. It is generally acknowledged that English is completely different from Indonesian language, such as the structure, pronunciation, and vocabulary. Vocabulary is one of the important things in learning English. Limited vocabulary make students could not state their ideas and opinion well students could not state their ideas and opinion well either in speaking or writing. If people have less vocabulary, they not only cannot understand other's saying, but also cannot 
make sentences to transfer their messages to the other people. So, they will understand English expressions if they have enough vocabularies.

English is an international language that must be used by everyone in the world. So, when someone, especially a student, masters English, of course they will be able to make it easier for them to adapt, speak and increase their knowledge. Since English is not a native language in Indonesia, it is very important for them to understand the basic part of learning the language, namely vocabulary. To make it easier for students to understand or memorize a lot of vocabulary, teachers or instructors need to master strategies to enrich students' vocabulary. They should be able to develop any kind of materials that make learning vocabulary will not become such boring and monotonous thing.

Moreover, in teaching English vocabulary, there are many methods that could help the students to enrich and improve their vocabulary. The teachers have to choose a appropriate method in teaching vocabulary, because it is not easy to teach English especially vocabulary without using suitable method. One kind of games is Spelling Bee Game. According to Rahayu (2002), there are some advantages in using Spelling Bee. It can improve students' spelling skill, vocabulary skill, comprehension in the text given and it also can be used by students to practice their concentration and their ability in memorizing.

One kind of games is Spelling Bee Game. According to Rahayu, there are some advantages in using Spelling Bee.2 It can improve students' spelling skill, vocabulary skill, comprehension in the text given and it also can be used by students to practice their concentration and their ability in memorizing. According to the National Spelling Bee, the purpose of Spelling Bee is to help students to improve their spelling, increase their vocabularies, learn concepts, and develop concert English usage that will help them all their lives.

Changes in the teaching vocabulary system from previously method or techniques (monotonous strategy) to games certainly have an impact on the teaching strategies used. Some studies show that teaching vocabulary through games can help students improve their vocabulary and other language skills. Results of study about the use of games in teaching vocabulary show that they provide students with an interesting, challenging and enjoyable atmosphere in classroom activities and they also contribute in helping the students to absorb materials more easily. Further, teaching vocabulary through spelling bee games can improve students' spelling skill, vocabulary skill, comprehension in the text given and it also can be used by students to practice concentration and their ability in memorizing. 
Teaching vocabulary are specific actions taken by the teacher of instructor to make learning easier, faster, more enjoyable, self-directed, more effective, and transferrable to new situations. As Jeanne explained, teaching vocabulary is about context and repetitionwhat they need to know about the words they're using, and using them multiple times. (Jeanne, 2007).

Changes in the teaching system from previously monotonous to using games impact the problems that students were facing. Furthermore, based on interviews with Seventh Grade students SMP 15 Kota Bengkulu, September 27, 2019. Data collection was carried out from the results of interviews. In the teaching vocabulary process, they claimed that they had experienced difficulties with the current teaching system. According to the Seventh Grade students, the researcher got information such as: 1). It was difficult to memorize English vocabulary, and forget it rapidly, 2). They could not pronounce the word correctly, 3). The students know very little about English vocabulary, when the teacher is saying the words, the students are confused because they do not to know what the teacher said, 4) The student feel boring in English classroom.

The lack of vocabulary created a barrier that discourages the students in learning English. So, it is a big challenge for the teachers to find an effective and efficient strategy in teaching vocabulary so that the teachers can help the students to memorize words better to improve their vocabulary achievement. They mentioned that they were always not motivated to learn new vocabulary. The pointed out they felt confused when they tried to give to correct meaning of new vocabulary and were unable to write the correct spelling of words in correct sentences. Moreover, they assured that their vocabulary weakness might stem from the unsuitable methods of teaching vocabulary provided to them by their instructors.

Teaching vocabulary strategies that will be applied by teachers, of course, each one has a specific purpose. Understanding the teaching strategy itself is an attempt to gain success and success in accomplish achievements. Strategy can be interpreted as planning contains a series of activities designed to achieve goals education. The teaching strategy of students is a series of activities learning carried out by teachers in order to achieve goals learn it.

Derived from the exceeding, the researcher focuses on enriching students' vocabulary mastery through games strategy. By all the explanation above the researcher decides to conduct the research entitled "Enriching Students' Vocabulary Mastery through 
English Spelling Bee Games at seventh Grade of SMP Negeri 15 Kota Bengkulu In Academic Year 2018/2019."

\section{B. Research Methodology}

This research employed an experimental research. An experimental design is to test the impact of a treatment on an outcome, controlling for all other factors that might influence that outcome. It is a quantitative research based on operational variables, statistics, computation and measurement. It concerns with finding out the effectiveness between two variables at the same time.

Based on Creswell (2009), Quasy-experimental is a form of experimental research in which individuals are not randomly assigned to groups. In this study, non-equivalent control group design was used. A non-equivalent groups design includes an existing group of participants who receive a treatment and another existing group of participants to serve as a control group.2 Participants are not assigned to group, but rather are assigned to the treatment group or control group along with all the others in their existing group. This design was chosen because the researcher did not break the classes up to get the objects of the study.

Tabel 3.1 Research design of Quasi Experimental Study

\begin{tabular}{|c|c|c|c|c|}
\hline $\begin{array}{c}\text { Non-equivalent } \\
\text { Group Design }\end{array}$ & Class & Pre-test & Treatment & Post-test \\
\hline Pre-test design & A & O1 & X & 02 \\
\hline Post-test design & B & 03 & & 04 \\
\hline
\end{tabular}

Where:
A : The experimental class
B : The control Group
O1 : Pre-test for the experimental group
O2 : Post-test for the experimental group
O3 : Pre-test for the control Group
O4 : Post-test for the control group

$\mathrm{X}$ : Treatment using Vocabulary English spelling bee games

In this research, the researcher was divided the subject of the study into two groups, an experimental group and a control group. Before and after the experiment, both of groups were given pre-test and post-test of vocabulary nowledge. Both of groups take pre-test (O1) 
and (O3) to measure their early vocabulary mastery before getting the experiment. During the experiment, the experimental group was taught by using English spelling bee games $(\mathrm{X})$, After the experiment, the same post-tests $(\mathrm{O} 2)$ and $(\mathrm{O} 4)$ were administrated to investigate whether any significant differences in learning vocabulary between the two groups.

The population of this study on the seventh grade students of SMPN 15 Kota Bengkulu in the academic year of 2019/2020. The number of population was 180 students. There were 6 classes of Seventh Grade. On the average, each class consists of student. Further, there are 60 students at the same level than is taken as sample. Further, the researcher choose two classes as the sample, and divides into two group, 30 students for the experimental group and 30 students for the control group. The researcher choose sample based on the same criteria homogeneity from students such as average score 6-7 from previous semester scores of English, Age 12-13 years taught by the same teacher. The sample class is VII D consisted of 30 students. The researcher took class VII D because the students' vocabulary is very low in this class with an average value of 42.3 . So, the researcher choses this class to seen whether there had a comparison or not in this class after researching and the problem in class VII D will be accordance with the title of the researcher and VII E to be the control group consisted for 30 students. Therefore, the total sample was 60 students.

The instrument of this research was test. The kind of test is vocabulary test where the test consists of pre-test and post-test. While the post-test was used to measure the students' vocabulary after the Spelling Bee game treatments. The test contained 20 items from which contain five options in each number. Moreover, in this research was used camera to take photos during teaching learning. It was used to documentation all the research process including documentation of answer sheets for test results that 6 have been tested. From giving the try-out, the pre-test, during the treatment class, and giving the post-test.

Here are the stages of doing data analysis using the quantitative analysis approach in more depth: a) analyzing normality, b) homogeneity, and c) analyzing t-test result and independent T-test. (Halvanes and Caputi, 2016).

\section{Results and Discussion}

\section{Results}


The following is the result of students' test in vocabulary mastery at Seventh grade students of SMP Negeri 16 Kota Bengkulu was increased.

a. The Result of Vocabulary test

1) The description of pre-test and post-test scores in experimental class Students' Pre-Test and Post-Test in Experimental Class

Graphically, the total score of the students pre-test and post-test in the experimental class can be seen in the appendix, In addition, it also shows the progress ( gain) occurring to each students.

Table 4.1 Description of Pre-test and Post-Test in the Experimental Class

\begin{tabular}{|l|c|c|c|c|c|}
\hline $\begin{array}{l}\text { Experiment } \\
\text { Group }\end{array}$ & N & Mean & $\begin{array}{c}\text { St. } \\
\text { Deviasi }\end{array}$ & Minimum & Maximum \\
\hline Pre-test & 30 & 60.17 & 11.78 & 40.00 & 85.00 \\
\hline Post-test & 30 & 76.00 & 10.62 & 55.00 & 95.00 \\
\hline
\end{tabular}

In the experimental class ( VII D ) the lowest score of pre-test was 40, then the highest score was 85 . And then, In the post-test scores, the lowest score was 55 and the highest score was 95 . These can be seen in the from the descriptive statistic of the pre-test and the post-test scores show in table 4.1 was found that the average of pre-test was 60.17 and the average score of post-test was 76.00. Graphically the total score of students pretest and post-test in the control class can be seen on figure 4.1

b. Repeating Strategy

1) Reading Strategy

In addition to the note-taking strategy, students often use the reading Figure 4.1 Graph for Pre-test and Post-test Scores in Experimental Class

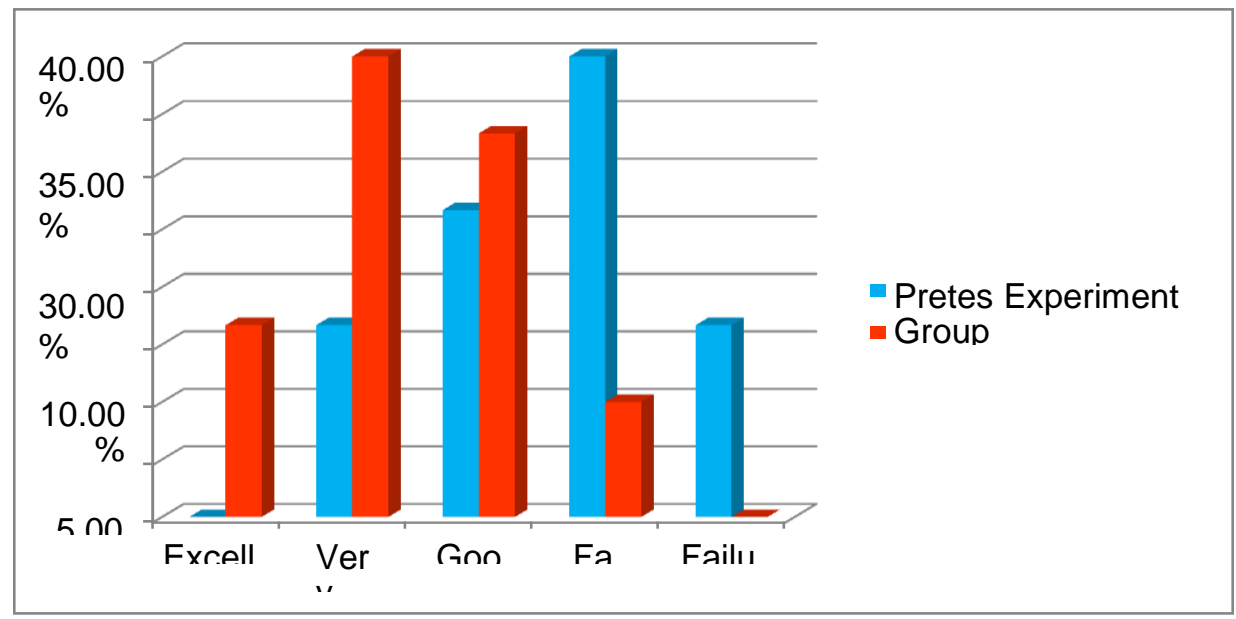


Based on figure 4.1, the post-test score was higher than Pre-test score. It means teaching vocabulary by using English spelling bee strategy could increase the student' vocabulary mastery score.

a. The distribution of Pre-Test and Post-Test scores in the Experimental Class can be seen on table 4.2.

Table 4.2

The Distribution in Experimental class

\begin{tabular}{|c|l|r|r|r|r|}
\hline \multirow{2}{*}{$\begin{array}{c}\text { Score } \\
\text { Interval }\end{array}$} & \multirow{2}{*}{ Category } & \multicolumn{2}{|c|}{ Pre-test } & \multicolumn{2}{c|}{ Post-test } \\
\cline { 3 - 6 } & & Frequency & Percentage & Frequency & Percentage \\
\hline $86-100$ & Excellent & 0 & $0.00 \%$ & 5 & $16.67 \%$ \\
\hline $71-85$ & Very Good & 5 & $16.67 \%$ & 12 & $40.00 \%$ \\
\hline $61-70$ & Good & 8 & $26.67 \%$ & 10 & $33.33 \%$ \\
\hline $50-60$ & Fair & 12 & $40.00 \%$ & 3 & $10.00 \%$ \\
\hline $0-49$ & Failure & 5 & $16.67 \%$ & 0 & $0.00 \%$ \\
\hline
\end{tabular}

Based on the table 4.2, the pre-test in the experimental group, there was 0 (0\% ) students in excellent category, 5(16.67\%) students were in very good category, 8(26.67\%) students were good category, 12(40.00\%) students were fair category, and 5( $16.67 \%)$ were failure category. While, in post-test, there was $5(16.67 \%)$ students in excellent category, 12(40.00\%) students were in very good category, 10(33.33\%) students were in good category, 3(10.00\%) students were in fair category, and $0(0 \%)$ students were failure category.

b. The description of Pre-Test and Post-Test Scores in the Control Class.

Table 4.3

Description of Pre-test and Post-Test in the Control Class

\begin{tabular}{|l|c|c|c|c|c|}
\hline $\begin{array}{l}\text { Control } \\
\text { Group }\end{array}$ & N & Mean & $\begin{array}{c}\text { St. } \\
\text { Deviasi }\end{array}$ & $\begin{array}{c}\text { Minimu } \\
\mathbf{m}\end{array}$ & $\begin{array}{c}\text { Maximu } \\
\mathbf{m}\end{array}$ \\
\hline Skor Pre-test & 30 & 59.83 & 15.34 & 20.00 & 90.00 \\
\hline Skor Post-test & 30 & 69.83 & 12.70 & 35.00 & 95.00 \\
\hline
\end{tabular}

In the control class ( VII E ) the lowest score of pre-test was 20, then the highest score was 90. And then, In the post-test scores, the lowest score was 35 and the highest score was 95. These can be seen in the from the descriptive statistic of the pre-test and the post-test scores show in table 4.3 was found that the average of pre-test was 59.83 and the average score of post- 
test was 69.83 .

Graphically the total score of students pre-test and post-test in the control class can be seen on figure 4.2

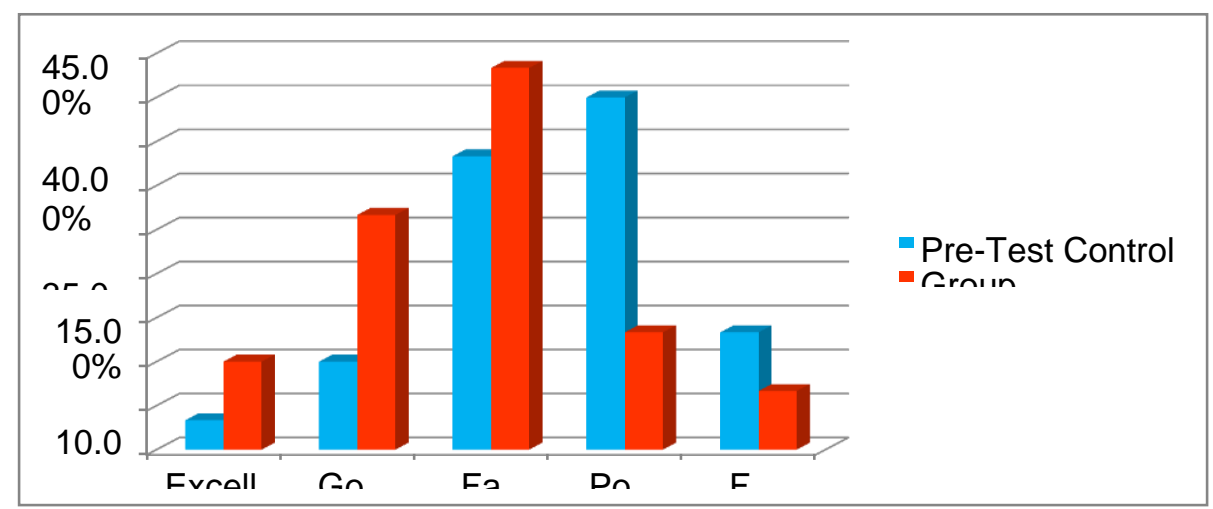

Figure 4.2

\section{Students' Pre-test and Post-test in Control Class}

Based on Figure 4.2, it was showed that the pre-test score and the post-test were relatively same. It means the score of students' vocabulary mastery increased gradually. The distribution of pre-test and post-test scores in the control class can be seen on table. 4.4.

Table 4.4

The Distribution in Class Control

\begin{tabular}{|l|l|l|l|l|l|}
\hline \multirow{2}{*}{$\begin{array}{c}\text { Score } \\
\text { Interval }\end{array}$} & \multicolumn{1}{c|}{ Category } & \multicolumn{2}{c|}{ Pre-test } & \multicolumn{2}{c|}{ Post-test } \\
\cline { 3 - 6 } & & Frekuensi & Persentase & Frekuensi & Persentase \\
\hline $86-100$ & Excellent & 1 & $3.33 \%$ & 3 & $10.00 \%$ \\
\hline $71-85$ & Very Good & 3 & $10.00 \%$ & 8 & $26.67 \%$ \\
\hline $61-70$ & Good & 10 & $33.33 \%$ & 13 & $43.33 \%$ \\
\hline $50-60$ & Fair & 12 & $40.00 \%$ & 4 & $13.33 \%$ \\
\hline $0-49$ & Failure & 4 & $13.33 \%$ & 2 & $6.67 \%$ \\
\hline
\end{tabular}

Based on the table 4.4 , the pre-test in control class there was $1(3.33 \%)$ students in excellent category, 3(10.00\%) students were in very good categoriy,10(33.33\%) students in good category, 12(40.00\%) students were in fair category, and 4( $13,33 \%)$ students were in very failure category. While in post-test there was 3(10.00\%) students were in Excellent category, 8( 26.67\%) students were in very good category, 13(4333\%) students were in good category, $4(13.33 \%)$ students were in fair category, and $2(6.67 \%)$ students were in failure 
category.

\section{The Normality and Homogeneity of the Data Score.}

Before analyzing the data, homogeneity and normality of the data should be measured. In determining homogeneity and normality of the data kolmogravsmirnov test used .

\section{a. The Result of Normality Data of Pre-test Score.}

In analyzing the normality of the data test of Pre-test scores, one sample Lielifors that used since the data of group less than 60 data. The test of normality and histogram of pre-test scores of the experimental group and pre-test scores of the control group can be seen on appendix 4 .

The kolmogorov-smirnov test of the pre-test of the experimental class showed that significance were 0.360 . Therefore, the significant value was higher than $\alpha$ $0,05(0.360>0.05) \mathrm{H}_{0}$ was accepted and it means the data was normality distributed.

In addition, The kolmogorov-smirnov test of the pre-test on control class showed that significance were 0.199 . Therefore, the significant value was higher than $\alpha 0,05(0.199>0.05) \mathrm{H}_{0}$ was accepted and it means the data was normality distributed.

\section{b. The Result of Normality Data Test of Post Test Scores.}

In analyzing data the normality of the data post-test scores, one sample Komogorov-smirnov test used since the data of each group less than 60 data. The test of normality and histogram of post-test scores on Experimental Class and Control Class can be seen on appendix 5 .

The kolomogrov-smirnov test of post-test on experimental class showed thatt significance were 0.404 . Therefore, the significant value was higher than $\alpha 0,05$ ( $0.404>0.05) \mathrm{H}_{0}$ was accepted and it means the data was normality distributed. The kolomogrov-smirnov test of the post-test of the control group showed that significance were 0.237 . Therefore, the significant value was higher than $\alpha 0,05$ ( $0.237>0.05) \mathrm{H}_{0}$ was accepted and it means the data was normality distributed.

\section{c. The Result of Homogenity of Variances Test.}

\section{1). Homogeneity of the Pre-Test.}

The homogeneity test of variances above that the Levene Statistic value 
shows 0.561 with the significant value were 0.457 . The result of homogeneity test was significant value was higher than $0.05(0.457>0.05)$. It means the sample in experimental class and in control class were homogeneous.

\section{2). Homogeneity of the Post-Test.}

The homogeneity test of variances above that the Levene Statistic value shows 0.561 with the significant value were 0.457 . The result of homogeneity test was significant value was higher than $0.05(0.457>0.05)$. It means the sample in experimental class and in control class were homogeneous.

\section{Independent Sample T-test Analysis of Students'Vocabulary Mastery.}

Before the research do the hypothesis independent statistical sample T-test, the researcher intentionally tested the difference in the average pre-test score first, to find out whether there were differences or not the Vocabulary Mastery of the Experimental Class and Control Class students before being given treatment. Because, based on the Normality test of the pre-test scores of the experimental class students and the pre-test scores of the control class students were declared normal, and the homogeneity test results were also stated by two groups is homogeneous, than test average difference used the T-Test Two Sample Independent, with Equal variances assumed.

\section{a. Different Average Test of Pre-Test Score.}

In order to find out whether or not there was significant different in Pre-Test Average between the students who were taught by using Spelling Bee and those who were not, the result were compared by using independent sample Ttest.

Based on the appendix 7, the value $\mathrm{T}_{\text {hitung }}$ was $0.094<\mathrm{T}_{\text {table }}=2.00172$ and Pvalue (sig.) $=0.925>0.05$. It means that $\mathrm{H}_{0}$ is accepted, so it can be concluded that the average Pre-Test scores of Experiment class students and control class students are the same. It means there was no difference in Vocabulary Mastery of the Experimental Class and Control Class students before being given treatment.

\section{b. Different Average Test of Post-Test Score.}

In order to find out whether or not there was significant different in Pre-Test Average between the students who were taught by using Spelling Bee and 
those who were not, the result were compared by using independent sample Ttest.

Based on the appendix 8 , the value $\mathrm{T}_{\text {hitung }}$ was $>\mathrm{T}_{\text {table }}=2.00172$ and Pvalue (sig.) $=0.046<0.05$. It means that $\mathrm{H}_{0}$ is rejected, so it can be concluded that the average Post-Test scores of Experiment class students and control class students are not same (different). It means a significant difference in Vocabulary Mastery between Experimental Class students and Control Class students after being given treatment. So it can be interpreted that the used of Spelling Bee Games is effective to improve student vocabulary.

\section{Discussion}

According to Hani Sutriana, the word "vocabulary" refers to a large numbers of words that students must to know, not only memorizing the form of the word but also understands the meaning. Vocabulary is not only confired to the meaning of the words but also includes how vocabulary in a language is structure, how people use the word, and how they learn of words (Hani Sutriani, 2012).

Meanwhile, Aminruddin stated that vocabulary is all the words that a person knows or use all the words in a language, or list of words with their meanings, especially in a book for learning a foreign language. Aminruddin explain that vocabulary is all the words that a person knows or use all the words in a language, or list of words with their meanings, especially in a book for learning a foreign language. (Aminruddin, 2012).

\section{High-achieving student learning strategies}

Student learning strategies are used to achieve a learning goal to be achieved in the learning. Not only that, learning strategies also refer to the behavior and thinking processes used by students that affect what is learned, including memory and metacognitive processes in the realization of teaching and learning activities to achieve the goals that have been set. Learning strategies are basically different for each student, especially for high achieving students. The difference in the implementation of this strategy is of course also influenced by the personal experience of each individual.

If you look more closely, you can see the similarities in the application of the learning strategies of the 9 research subjects. This equation is obtained by looking at the interview data that has been obtained. From the results of this study according to the research focus, there are 3 kinds of strategies used by 9 research subjects. With 
the following explanation: 6 out of 9 subjects used a note-taking strategy, 4 out of 9 used a reading strategy, and 1 out of 9 subjects used a recording strategy.

Furthermore, Oxford defines learning strategies as behaviors used by learners so that language learning is successful, directed, and enjoyable. These strategies are strategies that students use to solve certain learning problems. For example, students are often given the task of doing learning tasks such as making a summary of a particular material. They will automatically read the material given first and start making summary notes on the material (Oxford, 1990).

Although the successful completion of these tasks is the goal of learning, one essential thing is mastering the learning process itself: choosing an appropriate learning strategy and monitoring the strategy's effectiveness.

\section{Undesrstanding of student achievement learning strategies}

Based on the result of this study, there was no difference in vocabulary mastery between the experiment class and control class before the use of spelling bee Strategy at the seventh of SMP Negeri 15 Kota Bengkulu. However, there was significant difference in vocabulary mastery between the experiment class and control class used spelling bee games Strategy. In other words, the used of spelling bee games Strategy was effective toward improving students vocabulary mastery.

From the description of the research result above, there were some discussion that the researcher gave in this research some of them are about how English Spelling Bee strategy toward students' vocabulary mastery. Experiment and Control class 10 were the same in their initial level of vocabulary mastery. It was also proved by the researcher by indicating the initial level of vocabulary mastery by conducting the pretest that as given before the treatment. The mean score of pre-test in Experimental class was 60.17 and the mean score of Pre-Test in Control class was 59.83 statistically analysis has revealed that there was no significant effect in their PreTest scores of Vocabulary Mastery.

Based on the result of the research,the following interpretations are presented streng then the value of the research. Firstly, After doing the Post-Test, the result showed a statistically significant effect of Spelling Bee Games strategy toward students Vocabulary Mastery. The mean score of Post-Test in experimental class was 76.00 which was higher than the mean score of Post-Test in control class which was 
69.83. It showed that Spelling Bee Games strategy gave significant effect to students' vocabulary mastery.

Secondly, Spelling Bee Games strategy gave opportunities the students to develop their vocabulary through a deeper understanding conceptual knowledge, and they can enrich their vocabulary and remember the words easily, by these strategy, the students would not feel bored in learning because they did not get the monotonous process of teaching and learning in classroom, especially in learning vocabulary which consider by them as difficult and boring lesson.

\section{Conclusion and Suggestion}

\section{Conclusion}

Teaching vocabulary was clearly more than just presenting new words, vocabulary could be defined, toughly as the word taught in the language. Vocabulary development could be defined as the action or act of building up vocabulary or word the students had, or it can also said that vocabulary development in the elements of English that was being developed. Vocabulary mastery is receiving process of foreign language that happened intentionally or unintentionally. Students ${ }^{\text {ee }}$ vocabulary mastery is effort and performance of students ${ }^{\text {ee }}$ to gain or teach English vocabulary that is supposed through media teaching and learning process.

From the results of this study, it can be concluded that the English Spelling Bee is able toward students' vocabulary mastery. Most of the seventh grade students in the experimental class had better development and post-test scores than their score in pre-test. As students in the control class scored lower in the post-test. The result of this research indicate that using English Spelling Bee provides a significant different toward students' vocabulary mastery of what they found meaning word, and contributed to students for part of speech background knowledge before they even got questions. Therefore, in this research it means that English Spelling Bee we can toward students' vocabulary mastery at Seventh Grade Student in SMP Negeri 15 Kota Bengkulu 2020/2021.

\section{Suggestion}

a. Suggestion for teacher

They should vary different strategy to avoid the students` boredom in teaching learning process. They should find out appropriate strategy for teaching vocabulary. Moreover, they should be able to create teaching and learning 
process more interestingly, enjoyably, and educative in the classroom. Hence, it is highly recommended for the teachers to used vocabulary English Spelling Bee in 2 teaching vocabulary because of its effectiveness to help the students to improve their vocabulary mastery. It aids the students to develop their vocabulary through a deeper understanding conceptual knowledge. Therefore, they can enrich their vocabulary and remember the words easily. The teacher should has more selective in preparing the interesting activities, must provide a great variety of them and the teacher must creative.

b. Suggestion for students

They should be active, creative, and good work team on study. And then, they should ask the teacher if they find some difficulties in learning teaching, dare to answer questions, and pointing their friend. For the researcher, the result of this study can be used as reference or basic information to do further investigation, and can be apply this strategy on learning teaching in the class.

c. Suggestion for future researchers

Given the importance of the processes that occur in learning strategies to improve students' abilities, it is better to sharpen the focus of research to obtain a broader picture between students who use particular strategy and those who do not use unique strategy in learning. 


\section{References}

Creswell, J. (2009). Research design: qualitative, quantitative, and mixed methods approaches. Third Edition. Singapore: SAGE Publication, Inc.

Fromkin, Victoria and Rodman, R. (2001). An introduction to language. Victoria: Holt Rineheart and Winston.

Jhon, W. Best and Kahn, J.V. (2006). Research in education. USA: pearson education Inc.

Kasiran, M. (1948). Teknik analisis item' tes hasil belajar dan cara menghitung validity and reabsility. Surabaya: Usaha Nasional.

Lestari, T. N. (2018). Rubrik penilaian vocabullary. https:/www.scribd.com.

Louis, C. (2007). Designing and evaluating quantitative research in education, USA:Routledge.

Megawati, S. (2014). Improving students' tenses by using key word game to the eighth year students of SMPN 8 palopo. Palopo: STAIN Palopo.

Ningsih, D. (2011). Using online short functional text to improve the learning vocabulary ability of the English graders of SMAN 1 Palangka Raya. Malang: A thesis. graduate program in English language teaching, State University of Malang.

Ningsih, R,J. (2013). The use of spelling bee game to improve students vocabulary mastery. Universitas Pendidikan Indonesia.

Nurmiati. (2013). Teaching vocabulary though bingo game by using cooperative learning at the fifth elementary students' of SDN 61 Tondok Alla Jaya Palopo. Palopo: Stain palopo.

Rahayu, J.S. (2002). Spelling bee games in teaching narrative text. Bandung.

Read, J. (2000). Assesing vocabulary. Cambridge: Cambridge University Press.

Richards, J,C. and Willy, A,R. (2002). Methodology in language teaching. United States of America : Cambridge University.

Sari, M. (2016). Developing students' vocabulary through reading Short story at the eight grade of SMP PMDS Putra Palopo. Palopo: STAIN Palopo.

Sekarini, R. (2013). Implementating spelling bee games to improve seventh graders' spelling ability. English Language Education. Jurnal (http://jurnalonline.um.ac.id/data/artikel/C3169E3939E84BC613C 073DF90C8C.pdf.).

Siregar, A.Y. (2013). Improving Students' Vocabulary Mastery Through Crossword Puzzle North Sumatera: English Department of Education State Institute for Islamic Studies.

Sutriana, H.(2012). Vocabulary for daily conversation. Yogyakarta: Kawah Media.

Syamsul, S. (2015). Improving students' vocabulary through scrabble words game at the eighth year of SMPN 8 Palopo. Palopo: IAIN Palopo.

Wafa. N. (2017). Teaching studens' vocabulary by using spelling bee game of the second year students at SMPN 3 Sungguminasa Gowa. Makasar: Universitas Islam Negri Alauddin Makassar. 